JAN SAMEK

\title{
KAZIMIERZ LESIOWSKI, MALARZ FRANCISZKAŃSKI WIEKU XVII I PROBLEM ARTYSTÓW ZAKONNYCH W SZTUCE POLSKIEJ EPOKI BAROKU
}

Nazwisko Lesiowskiego, jak i wielu artystów - Polaków, wydobył z zapomnienia zasłużony badacz ,starożytności polskich”, Ambroży Grabowski. Świadczy o tym następująca wzmianka umieszczona w książce Ojczyste spominki.... „X. Lesiowski Kazimierz. Zakonnik ten trudniący się kunsztem malarskim, płodami pędzla swego upiększył klasztor tychże ojców chelmińskich". X. Ludwik Miske w rękopisie Sinoptica relatio Conventuum etc. wspomina z pochwałą o dziele ręki jego, to jest o stallach mieszczących w sobie piękne malowanie. „Przed wielkim ołtarzem jest chór dwoma rzędami stallów opatrzony, który dwudziestu czterech braci wygodnie objąc mogą. Te są wcale gładko zbudowane, kolorytem srebrzystym pociągnione i przy tem ozdobione obrazami dziwnej rozmaitości, które malował O. Kazimierz Lesiowski, zakonnik nasz. Wyobrażało ono od strony ewangelii dzieje żywota św. Franciszka, od strony epistoły życie św. Antoniego z Padwy". - O czasie, w którym ten ojciec żył, żadnej X. Miske nie uczynil wzmianki ${ }^{1}$. Notatkę tę opublikowano w r. 1845, w pięć lat później posłużył się nią Edward Rastawiecki w słowniku malarzy polskich ${ }^{2}$.

Z kolei wzmiankę o Lesiowskim umieścił w swym słowniku Julian Kolaczkowski ${ }^{3}$. Na dalszą wzmiankę o Lesiowskim czekać trzeba będzie

1 A. Grabowski, Ojczyste spominki w pismach do dziejów dawnej Polski. I. Kraków 1845, S. $250-251$.

${ }^{2}$ E. Rastawiecki, Stownik malarzów polskich, tudziez obcych w Polsce osiadlych luh czasowo wiej przehywajacych. I. Warszawa 1850, s. 260-261.

${ }^{3}$ J. Kołaczkowski, Wiadomości tyczqce sie przemyshu i sztuki w dawnej Polsce. KrakówW'arszawa 1889, s. 309. 
z górą lat czterdzieści, dopiero bowiem w r. 1929 krótki życiorys, a właściwie notatka o artyście znalazła się w słowniku Thiemego i Beckera a opracował ją Marian Gumowski ${ }^{4}$. Niestety, w informacji Gumowskiego, który nie wyszedł poza wiadomości podane przez Grabowskiego, umieszczona została na niczym nie oparta informacja, iz był to malarz polski działający w wieku XVIII.

Rzecz sprostował, niezależnie od krótkiego opracowania Gumowskiego, Bolesław Makowski, który nie tylko stwierdził, że prace w Chełmnie wykonane były ok. r. 1630, ale również (niestety bez przekonywających dowodów) związał z osobą Lesiowskiego polichromį̨ i dekorację drzwi oraz malowidła w stallach z 1. dekady w. XVII z kościoła pobernardyńskiego w Lubawie ${ }^{5}$. Makowski wyjaśnił również, że stalle w Chełmnie uległy zniszczeniu po kasacie zakonu, która miała miejsce w r. 1806; kościół czynny był jeszcze do r. $1828^{6}$. Jako ostatnią pozycję dotyczącą Lesiowskiego wymienić należy hasło opracowane przez autora niniejszego artykułu dla Polskiego Slownika Biograficznego ${ }^{7}$. Obecnie powracamy jeszcze raz do tego tematu, ponieważ odnalezione przy pracach nad Katalogiem $m$. Krakowa sygnowane dzieło artysty ${ }^{8}$ pozwala nie tylko na pewniejsze umiejscowienie w czasie, ale i na wstępną charakterystykę twórcy.

Dzielem tym jest okazaly obraz przedstawiający św. Antoniego Padewskiego, przechowywany $w$ dużej sali zwanej kapitularzem $w$ klasztorze klarysek przy kościele Św. Andrzeja w Krakowie (fig. 1-2). Malowidło u klarysek posiada spore wymiary $(189 \times 106 \mathrm{~cm})$, wykonane zaś zostało przy użyciu farby olejnej na plótnie. Oprawione jest w zapewne współczesną obrazowi ramę dekorowaną ornamentem chrząstkowo-małżowinowym. Pośrodku plótna przedstawiono frontalnie św. Antoniego w czarnym habicie zakonnym, dzierżącego $w$ prawej ręce lilię o trzech pękach i dwóch rozkwitlych kwiatach. W lewej ręce Swięty trzyma skośnie opartą o biodro książkę ceglastego koloru, na której stoi we wdzięcznej pozie Dzieciątko Jezus (fig. 3). Dookoła głowy zakonnika zaznaczono szeroki nimb, przechodzący od koloru żółtego w jasny brąz; oprawa księgi ma barwę bladej, ceglastej czerwieni. Małego Jezusa przedstawiono w sukience $\mathrm{z}$ delikatnej,

4 M. Gumowski, Lesiowski Kasimir. Thieme-Becker ,Allgemaines Lexikon der bildenden Künsller”.... XXIII. Lepizig 1929, s. 123.

${ }^{5}$ B. Makowski, Sżuka na Pomorzu. Jej dzieje i zahytki. Toruń 1932, s. 98, 10-101, 122.

${ }^{6}$ Tamże, s. 122; Por. też T. Mroczko, Dawny powiat chelmiński. W: Katalog Zahytków Sztuki w Polsce. Dawne województwo bydgoskie. Z. 4, Warszawa 1967, s. 31.

7 J. Samek, Lesiowski Kazimierz (1. pol. XVII w.), malarz, franciszkanin. W: Polski Slownik Biograficzny XVII. 1972, s. 91.

${ }^{8}$ Kościoly, klasztory Śródmieśsia 1. Katalog Zahytków Szatuki w Polsce. IV. Miasto Kraków. Cz. II. Klasztor klarysek. Oprac. K. Dżułyńska, J. Chojecka. Warszaw 1971, s. 64, fig. 322. Sygnatura ta została zanotowana w czasie prac redakcyjnych. 
przejrzystej materii w czerwone i niebieskie kwiaty, przyozdobionej koronką. Na sukienkę tę narzucona jest wierzchnia szata w ceglastym kolorze; wokół główki zaznaczono delikatnie białe pęki promieni. Postać zakonnika wypełnia niemal całą wysokość malowidła. W tle, z lewej strony, (heraldycznie) wyobrażono kolumnę stojącą na wysokim postumencie, z prawej zaś w dalekiej perspektywie bazylikę S. Antonio w Padwie, przedstawioną jak wskazuje porównanie, dość wiernie (fig. 4-5) ${ }^{9}$. Warto dodać, że malarz nie pominął $w$ tym widoku ani charakterystycznych kopuł, ani wieży w krzyżu kościoła, nie mówiąc już o plaskich dachach i wzmacniających ściany szkarpach. Przestrzeń ponad bazyliką, przedstawioną z użyciem bieli, róży i delikatnych brązów ożywił malarz skłębionymi chmurami. W przedstawieniu Świętego uderza pewien hieratyzm, bardzo słaby ruch i sumaryczne potraktowanie owalnej twarzy. Koloryt jest ograniczony, główny akcent stanowi czerń habitu, w tle zastosowano biele, róże i brązy (widok bazyliki w Padwie). Uderza również brak większej plastyki w wizerunku wybitnego franciszkanina. Nie dodaje jej rozproszone światło, które zdaje się padać z lewej strony.

W lewej, dolnej. części malowidla umieszczono napis VERA EFFIGIES DIVI ANTONII DE PADVA. Autorstwo i czas powstania obrazu określa sygnatura: „1648 prima sept[embris] F. Casimir[us] Lesiowski (fig. 6).

Obraz u klarysek nie jest zapewne jedynym jaki wykonał Lesiowski dla krakowskich klasztorów. Zbliżone w kompozycji do omówionego jest duże malowidło, znajdujące się w refektarzu krakowskiego klasztoru franciszkańskiego (fig. 7) ${ }^{10}$. Obraz ten znajdował się niestety w złym stanie i uległ w r. 1969 konserwacji; w rezultacie malowidło wydaje się być dość silnie zmienione. Świętego przedstawiono tu również w calej postaci, w pozycji frontalnej $w$ ten sposób, że wypełnia on niemal calą wysokość obrazu. Brak jednak Dzieciątka. Święty w lewej ręce trzyma książkę, lilię o trzech rozkwitłych kwiatach i dwóch pękach oraz różaniec; prawą uniósł do góry w geście błogosławieństwa. Twarz jest lekko modelowana światlem, które pada $z$ prawej strony. Lewą partię malowidła w całości zajmuje wydatny cokół z kolumną; z prawej dostrzegamy, jak i w obrazie u klarysek, bazylikę w Padwie. I tu zanotować wypada wierne w stosunku do oryginału odtworzenie budowli; partie tła ponad bazyliką wypełnił malarz kłębiastymi obłokami. Całość, na skutek silnego odnowienia, jest dość trudna do oceny $\mathrm{z}$ artystycznego punktu widzenia. Ze względu na zbliżoną

- Folografie bazyliki w Padwie dostarczył mi mgr Kazimierz Kuczman, któremu składam na tym miejscu serdeczne podziękowanie.

10 Kościoly $i$ klasztory Śródmieścio I, s. 127 (klasztor franciszkanów. Oprac. P. Maliszewski i A. Małkiewicz). 
kompozycję, frontalność przedstawienia, słaby światłocień, pewną hieratyczność postaci, wydaje się możliwe, że i ten obraz wyszedł spod pędzla Kazimierza Lesiowskiego.

Dwa malowidła, w tym jedno sygnowane, to zbyt mało, aby spróbować scharakteryzować malarza, warto jednak podjąć taką próbę. W świetle zachowanego dzieła jakim jest obraz od klarysek, Kazimierz Lesiowski zarysowuje się jako malarz znający swoje rzemiosło. Prawidłowo oddaje proporcje postaci ludzkiej, naturalnie $\mathrm{z}$ zastosowaniem właściwych dla czasu w którym tworzyl, uwysmuklonych proporcji; nieźle radzil sobie także $\mathrm{z}$ ruchem postaci i wydobyciem pewnej plastyki za pomocą w umiarkowany sposób używanego światłocienia. Dosyć interesujący jest koloryt, w którym występują charakterystyczne dla manieryzmu blade czerwienie. Jak wskazują notatki archiwalne, stać go było także na większe cykle (obrazy z kościoła franciszkanów w Chełmnie).

Dla nas postać ta może być interesująca z kilku punktów widzenia. Podkreślenia wymaga fakt, iż przedstawienie św. Antoniego od klarysek należy do niezbyt licznie zachowanych wyobrażeń tego świętego, jakie rozpowszechniły-się w Polsce $w$ siedemnastym wieku. Ważną rolę odegrał tutaj obraz św. Antoniego z Padwy z kościoła franciszkanów w Warszawie (fig. 8), malarza królewskiego Mateusza Bertowicza z r. $1664^{11}$.

Swiętego Antoniego malował także bernardyn, Franciszek Lekszycki. Obrazy o tej tematyce zachowaly się w Kalwarii Zebrzydowskiej, w kaplicy poświęconej św. Antoniemu przy kościele bernardynów (z ok. 1641 ?), u bernardynów w Przeworsku (z. 1. 1645-1649) oraz w ołtarzu kościoła bernardynów (z l. 1659-64) w Krakowie (fig. 9) ${ }^{12}$. Jak $\mathrm{z}$ powyższego wynika, malowidło pędzla Kazimierza Lesiowskiego zajmuje pośród przedstawień św. Antoniego w Polsce poczesną pozycję. Prawdopodobnie jest to jedno z najwcześniejszych, siedemnastowiecznych przedstawień tego Świętego w Krakowie.

Obraz Lesiowskiego budzi zainteresowanie również z innego punktu widzenia. Mianowicie można by go nazwać, jeśli idzie o zaaranżowanie przedstawienia z wyobrażeniem Świętego -- ,portretowym”. Przypomnieć tu wypada, że św. Antoni przedstawiony na nim został w ten sposób, że

11 Por. T. Dobrzeniecki, J. Ruszczycówna i Z. Niesiołowska-Rotherowa, Sztuka sakralna w Polsce. Malarstwo, s. 352; M. Walicki, W. Tomkiewicz i A. Ryszkiewicz, Malarstwo polskie. Manieryzm. Barok. Warszawa 1971, s. 371-372. Informacji o ostatecznym ustaleniu autorstwa obrazu u franciszkanów w drodze odnalezienia peinej sygnatury udzielił mi ks. dr Baran.

12 J. Samek, Lekszycki Franciszek (ok. 1600-1668) malarz zakonny, bernardyn. W: Polski Slownik Biograficzny. XVII, 1972, s. 15; Walicki, Tomkiewicz i Ryszkiewicz, Malarstwo polskie..., s. 370-371; K. Kantak, J. Szablowski i J. Zarnecki, Kościól i klasztor bernardynów w Krakowie. „Biblioteka Krakowska” Kraków 96, Kraków 1938, s. 128-129. 
zajmuje niemal całą wysokość malowidła, w tle zaś występuje kolumna - motyw częsty w polskim malarstwie ${ }^{13}$ - mający swoje źródlo w sztuce obcej. Do obserwacji o portretowym potraktowaniu obrazu świętego Antoniego u klarysek dodać jeszcze należy specyficzny stosunek do realiów, który powoduje, że w malowidle postać zakonnika zdecydowanie wybija się na plan pierwszy. Można by więc nazwać obraz niejako portretowym przedstawieniem świętego franciszkanina, naturalnie w rozumieniu przyjęcia pewnego typu kompozycji. Warto dodać, iż do tego rodzaju wizerunków należy także znany obraz św. Kazimierza z kościoła reformatów Wrakowie, powstały ok. poł. w. XVII ${ }^{14}$. Do portretu nawiązuje również między innymi obraz św. Barbary w Odolanowie z r. 1618, z umieszczonym na odwrocie napisem i datą „Joannes Poniecki 1658”. W malowidle tym została również umieszczona kolumna, święta zaś stoi na tarasie ${ }^{15}$. W przyszlości do kompozycji tego typu z pewnością da się zaliczyć znacznie więcej obiektów. $\mathrm{Na}$ razie pragniemy zasygnalizować, że pośród licznych rozwiązań, jakie rozpowszechniły się w naszym malarstwie w siedemnastym stuleciu, występuje także typ przedstawień świętych nawiązujących do wyobrażeń portretowych.

Osobnym zagadnieniem, które nasuwa się w związku z omawianym obrazem Lesiowskiego, jest problem twórczości artystów zakonnych w Polsce. Do problemu tego zebrano w ciągu szeregu lat badań nad malarstwem w: Polsce dużo materiałów; osobno zajmowano się nim jednak w niewielkim stopniu ${ }^{16}$.

Ze zgromadzonych dotąd danych wynika, że w zakonach trudniono sie w początku w. XVII, naturalnie i wcześniej, malarstwem, snycerstwem oraz innymi rzemiosłami, jak stolarstwo. Wykonywano także hafty. Zjawisko to zaobserwować można w licznych i męskich i żeńskich klasztorach, m-in. u bernardynów, kanoników regularnych laterańskich, dominikanów, bernardynek, benedyktynek, franciszkanów i reformatów; zresztą znacznie

${ }^{23}$ Por. T. Dobrowolski, Polskie malarstwo portretowe. (Ze ze studjów nad szluką epoki sarmatyzmu). Kraków 1948, tabl. 61, 70, 72, 118, 128, 129.

4 K. Bartel, Ohraz św. Kazimierza w kościele OO. Reformatów w Krakowie. „Biuletyn Histoni Sztuki" XXX (1968). Z. 1, s. 62-72, il. 1; Walicki, Tomkiewicz i Ryszkiewicz, Malarsimo polskie.... s. 346-347.

is A. Kodurowa, Powiat ostrowski. „Katalog Zabytków Sztuki w Polsce” V. Województwo posnariskie, z. 16, Warszawa 1958, s. 9, fig. 28.

I0 L“wagi syntetyczne o dzialalności artystów zakonnych w Polsce sformulowali dotąd: M. Sokolowski. Z dziejów kultury i sztuki. ,Sprawozdania Komisji Historii Sztuki” VI, s. 99; M. Morelowski, Пyniki poszukiwan za nieznanymi artystami XVI $i$ XVII w. „Prace Komisji Historii Sztuki" III (1920), s. XCI-XCII; najwięcej miejsca temu problemowi poświęcili jednak Dobrowolski, Polskie malarstwo..., s. 164-165 i nn., M. Gębarowicz, Szkice z historii saluki XVIJ w. Towarzystwo Naukowe w Toruniu. „Prace Wydziału Filologiczno-Filozoficznego" XVI, z. 3, Toruń 1966, s. 95-107. 
łatwiej powiedzieć, gdzie je uprawiano, aniżeli gdzie ich nie uprawiano. Może najwyraźniej zaobserwowano dotąd wspomniane zjawisko w malarstwie $^{17}$ i snycerstwie ${ }^{18}$.

W rezultacie zaliczyć można Kazimierza Lesiowskiego do większej grupy artystów zakonnych, czynnych w Polsce w 1. i 2. tercji w. XVII. Jeśli chodzi o całość badanego zjawiska, nie tylko w odniesieniu do malarstwa, wysunięto ostatnio dość interesujące hipotezy. Uczynił to Mieczysław Gębarowicz, zwracając uwagę na fakt, że z artystami zakonnymi w dziedzinie snycerstwa lączą się realizacje większych zamierzeń artystycznych, których wykonanie przekraczało możliwości pojedynczych osób. Przykładem mogą być stalle wykonywane w klasztorach dominikanów, bernardynów, czy franciszkanów. Autor hipotezy stoi na stanowisku, że dzieła artystów zakonnych nie są jakąś odmienną enklawą twórczości danego środowiska, lecz stanowią niejako probierz poziomu możliwości twórczych ${ }^{19}$. Ze swej strony pragniemy dodać tutaj dalsze spostrzeżenia. Wydaje się, że wykonywane przez artystów zakonnych obrazy, sprzęty czy inne wyroby posiadają jednak pewne cechy odrębne. Cechy te miały różne uwarunkowania.-Specyficzny charakter dziel wykonywanych w klasztorach często wynikał z faktu, ze ich autorzy byli samoukami. Niewątpliwie na pierwszy plan wysuwał się też pewien utylitaryzm - przeznaczenie obrazu czy sprzętu, tendencje do nadania mu cech okazałości - czy na odwrót - ograniczenie dekoracji, jeśli wymagała tego reguła. Oddziaływały tutaj także i inne czynniki. Często wzorowano się na wybitnych, znanych dziełach w macierzystych klasztorach. Przykładowo warto przypomnieć ambony w kształcie łodzi, naśladujące kazalnicę z kościoła Bożego Ciała kanoników regularnych laterańskich na Kazimierzu w Krakowie, którą powtórzono w innych kościołach tego zakonu, m.in. w Klobucku a nawet u ŚS. Piotra i Pawła na Antokolu w Wilnie ${ }^{20}$. Istnieją też pewne, można

${ }^{17}$ Materiały do malarzy zakonnych dostarczają m.in. prace: Grabowski, Ojczyste..., Rastawiecki, Slownik malarzów..., I-II Warszawa 1850, s. 57; W. Gąsiorowski, Cechy krakowskie ich dzieje $i$ ordynacje. Kraków 1860; W. Luszczkiewicz, „Sprawodzania Komisji Historii Sztuki" IV, IX; Tenże, Malarstwo religijne w Polsce. W: Encyklopedia Kościelna Nowodworskiego. Warszawa 1880, s. 171; M. Skrudlik, Tomasz Dolabella. „Rocznik Krakowski" XI, s. 144 i nn.; F. Kopera, Dzieje malarstwa w Polsce. I-II, Kraków 1925-26, s. 138; A. Gosieniecka, Problem tradycjonalizmu malarstwa wielkopolskiego za panowania Zygmunta III. „Sprawozdania Poznańskiego Towarzystwa Przyjaciół Nauki” nr l (36) 1947, s. 119; Z. Hornung, Stanislaw Stroinski 1719-1802. Zarys monograficzny ze szczególnym uwaględnieniem dzialalności artysty na polu malarstwa ściennego. „Prace Sekcji Historii Szluki i Kultury Towarzystwa Naukowego we Lwowie". II, 1935, s. 13 n.

18 Por. Gębarowicz, Szkice..., s. 104, 107.

19 Tamże, s. 104.

20 Por. J. Samek, Ambony naves et naviculae. Rokoko. W: Studia nad sztuka 1. polowy XVIII w. Warszawa 1970, s. 219-223; Tenże, Pozycja kościola Bożego Ciala w sztuce 
by powiedzieć ulubione techniki, które stosowano w wytwarzanych w klasztorach wyrobach. Mamy tu na myśli powszechnie stosowaną w ,klasztornym" stolarstwie intarsję, o popularności której świadczą choćby siedemnastowieczne stalle u bernardynów w Sierakowie i Leżajsku oraz analogiczne wyroby pochodzące $\mathrm{z}$ w. XVIII u dominikanów i reformatów w Krakowie ${ }^{21}$. Dzieła artystów zakonnych cechuje także stosowanie właściwych dla danych zakonów tematów ikonograficznych. Można więc powiedzieć, że mimo związków z produkcją cechową sztuka artystów zakonnych stanowi odrębne zjawisko artystyczne, w którym rządzą inne prawa i dochodzą do glosu inne wartości. Należałoby więc postulować opracowanie ich dziel, czego przykład stanowić może wydany przed kilku laty slownik artystów jezuickich ${ }^{22}$.

Do tej grupy twórców, jak wspomnieliśmy, należy Kazimierz Lesiowski Konkretnie do parających się malarstwem zakonników, idąc dalej do malarzy zakonów franciszkańskich (o których wiemy sporo), ostatecznie zaś określając zjawisko, do malarzy zakonu franciszkanów. Warto tutaj przypomnieć, że obok innych artystów działali w nim tacy twórcy, jak ks. Faustyn Proszowski w Proszowie, zmarly w 1715 w. w konwencie bie$\operatorname{chim}^{23}$.

Kończąc warto dodać, że na rozpowszechnianie się różnego rodzaju wytwórczości w klasztorach, mogły również oddziaływać specjalne wydawnictwa. Przypomnieć tutaj można druk poznański z r. 1689, zapewne dzielo jezuity, który stanowi po prostu zbiór przepisów na wykonanie sposobem „gospodarczym" najrozmaitszych przedmiotów wchodzących w. zakres rzemiosła, a należących do wyposażenia kościołów i mieszkań ${ }^{24}$. W książce tej mowa jest m.in. jak wykonać naśladownictwa haftów, drogich kamieni czy marmuru. Tego rodzaju przepisy niewątpliwie ułatwialy twórczość nieprofesjonalną w klasztorach, o czym miałem okazję już móuić na Zjeździe Towarzystwa Ludoznawczego w Krakowie w roku $1976=5$.

$K_{r=-i o-a}$ oraz jego rola $w$ poczynaniach artystycznych kanoników regularnych kongregacji uratonsajej. W: Studia z dziejów kościola Bożego Ciala w Krakowie. Kraków 1977, s. 33.

24 Por Kościoly i klasztory Śródmieścia 2. Katalog Zabytków Sztuki w Polsce IV. Miasto Kraków. cz III, s. 1, 3, 9, 138, 139 (klaszlor reformatów opracował M. Gutowski, klaszlor Dĩjerów opracowali A. Olszewski i W. Bochnak).

I. Poplatek i J. Paszenda. Slownik jezuitów artystów. Kraków 1972.

23 Dobrowolski, Polskie malarstwo..., s. 164.

to Sekret wyjawiony osobliwszy ten, za który czlowiekowi rozsadnemu chyba chcacemu, Eatine tle na swiecie szkodzić nie bęzie. Rzeczy pewne i doświadczone na dobro pospolite. Za dozmoleniem Siorsach do druku podane. W roku 1689 w Poznaniu. W drukarni Collegiy Soc. IESL Roku 1689; cyt. wg J. Eckahardi, Rzemiosto artystyczne do końca XIX w. Por. Dziesięć wiekón Poznania III. Szluki plastyczne. Poznań-Warszawa 1956, s. 234, 235-36. 
Reasumując, można działalność franciszkanina Kazimierza Lesiowskiego uważać za jeden z objawów, jak pisał Mieczysław Gębarowicz, charakterystycznego zjawiska pojawienia się ,,w pierwszej połowie XVII w. nowych ośrodków twórczości artystyczno-rzemieślniczej w postaci artystów i warsztatów klasztornych" 26 .

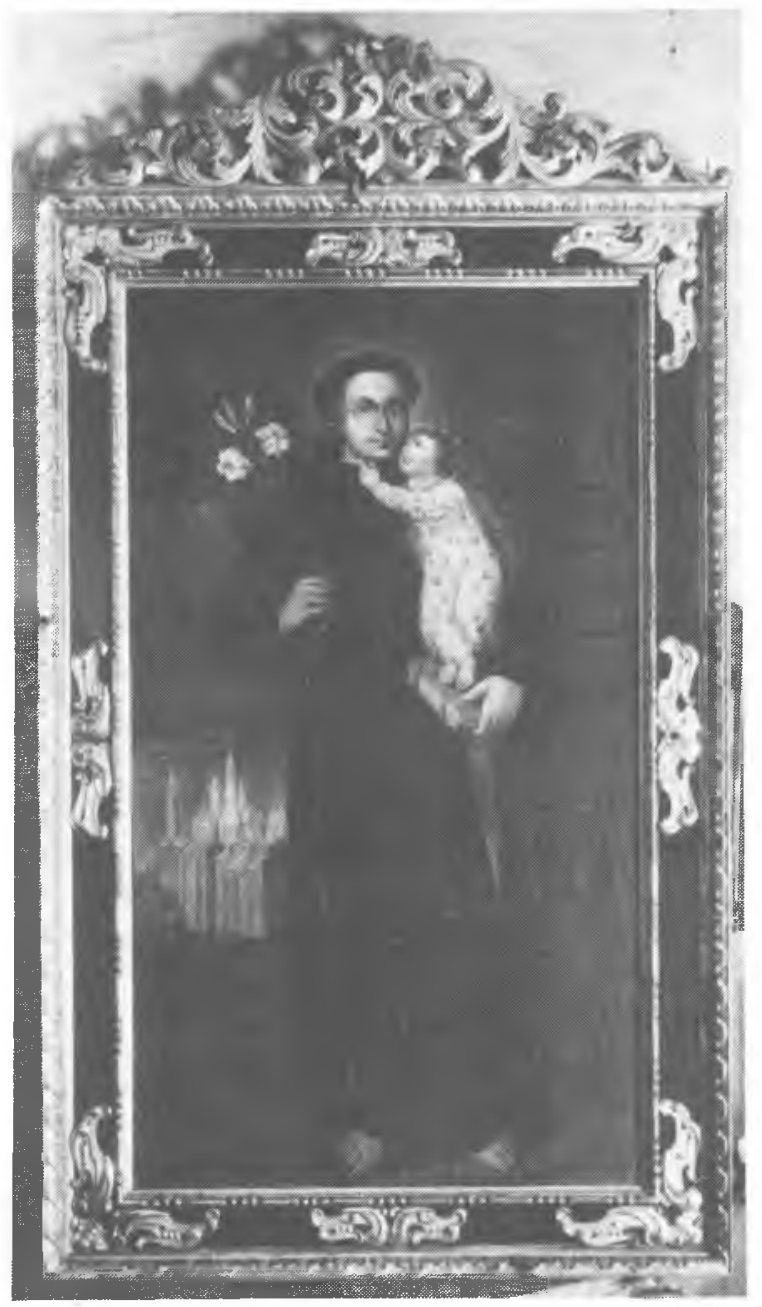

1. Sw. Antoni z Padwy, obraz z r. 1648 wraz z obramieniem w kapitularzu klasztoru klarysek przy kościele Św. Andrzeja w Krakowie (fot. E. Kozłowska-Tomczyk)

26 Gębarowicz, Szkice..., s. 95. 


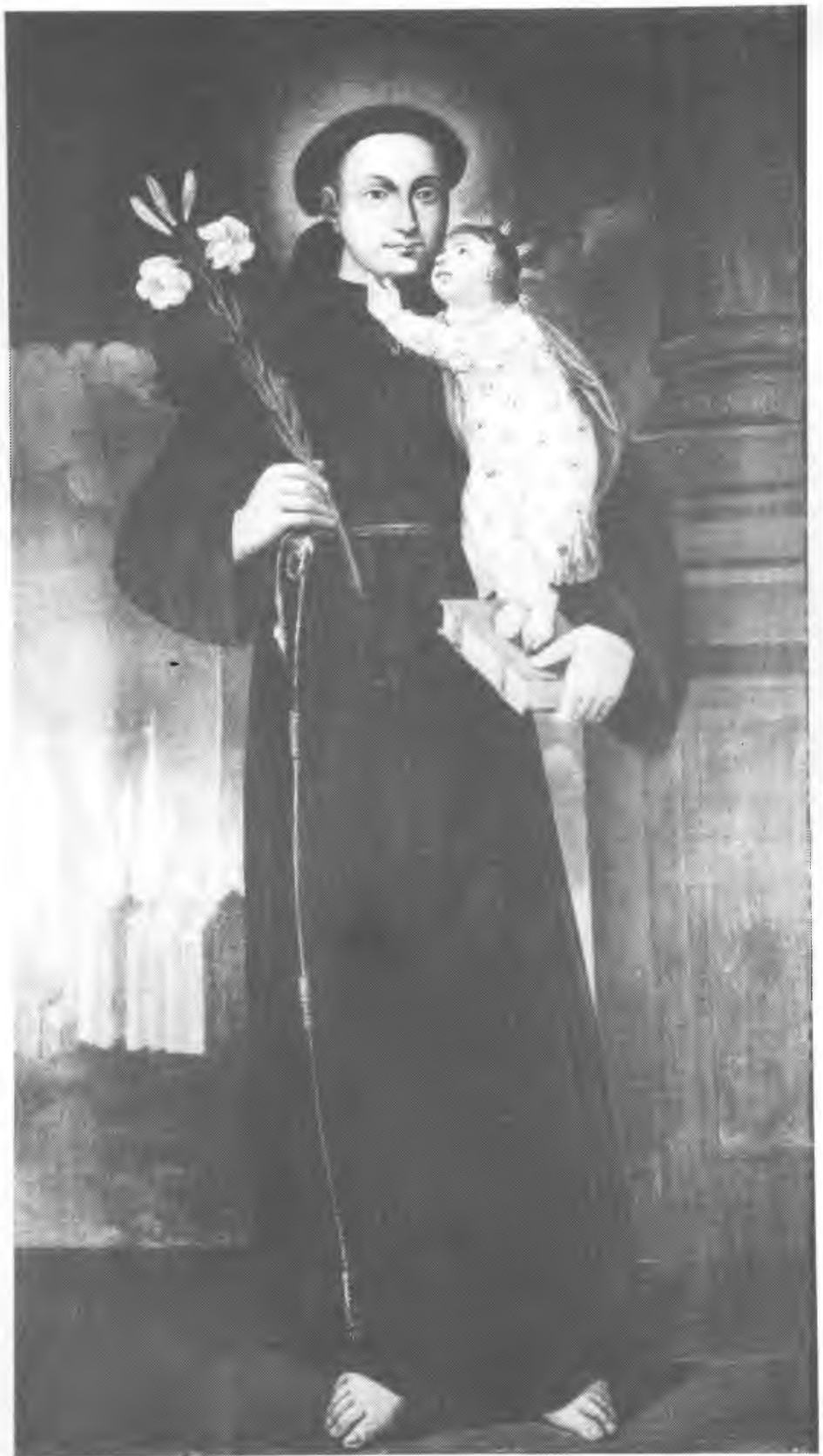

2. Su. Antoni z Padwy, obraz z r. 1648 w kapitularzu klasztornym klar: sek przy kościele Św. Andrzeja w Krakowie (fot. M. Samek) 


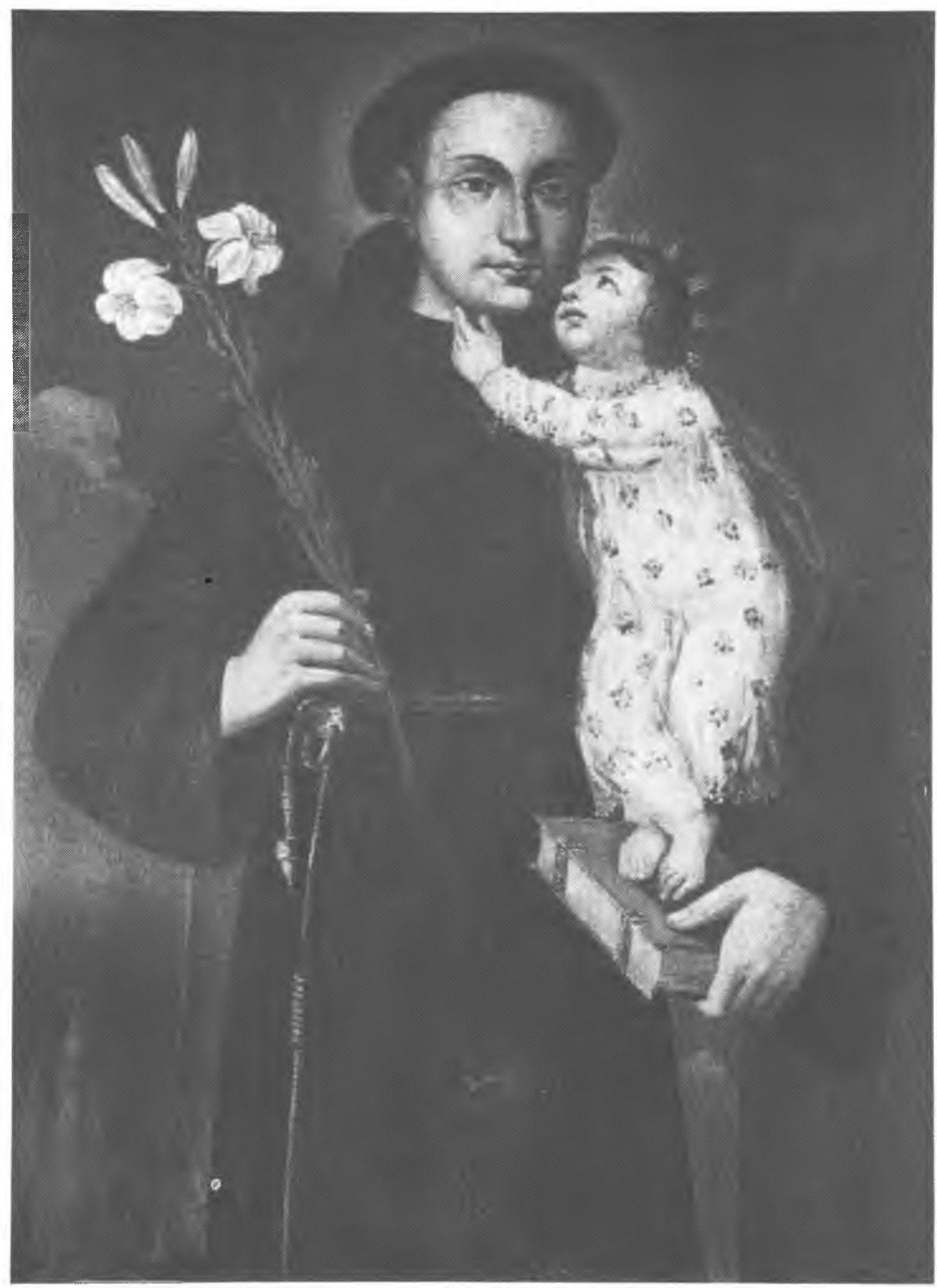

3. Część górna obrazu św. Antoniego z Padwy z r. 1648 w kapitularzu klasztoru klarysek przy kościele Św. Andrzeja w Krakowie (fot. M. Samek) 


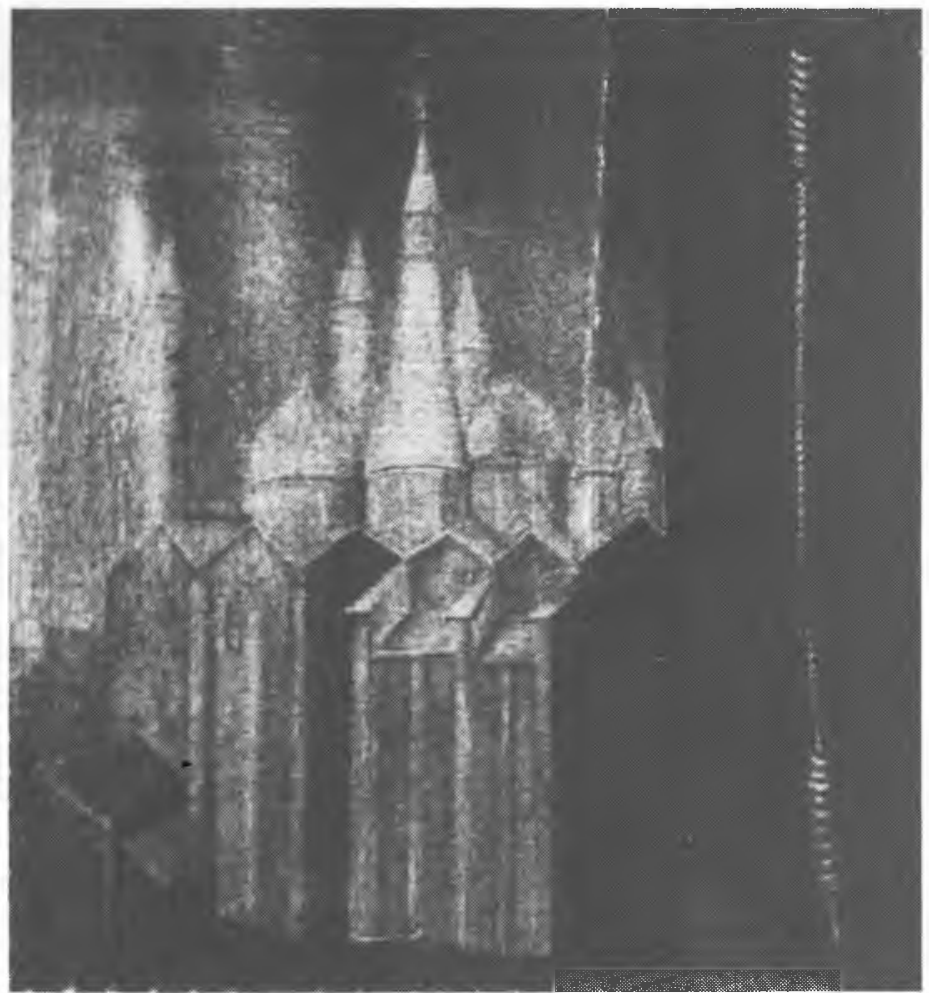

4. Bazylika Św. Antoniego w Padwie, szczegól obrazu św. Antoniego z Padwy z r. 1648 w kapitularzu klasztoru klarysek przy kościele Św. Andrzeja w Krakowie (fot. M. Samek)

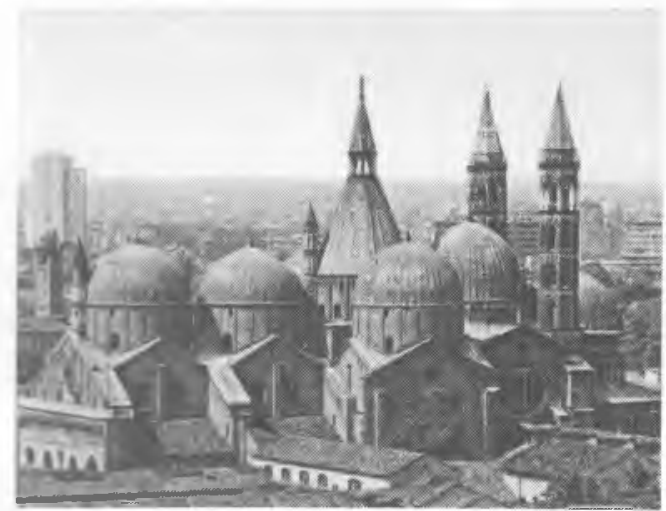

5. Bazylika Św. Antoniego w Padwie (fot. wg zdjęcia w posiadaniu autora) 


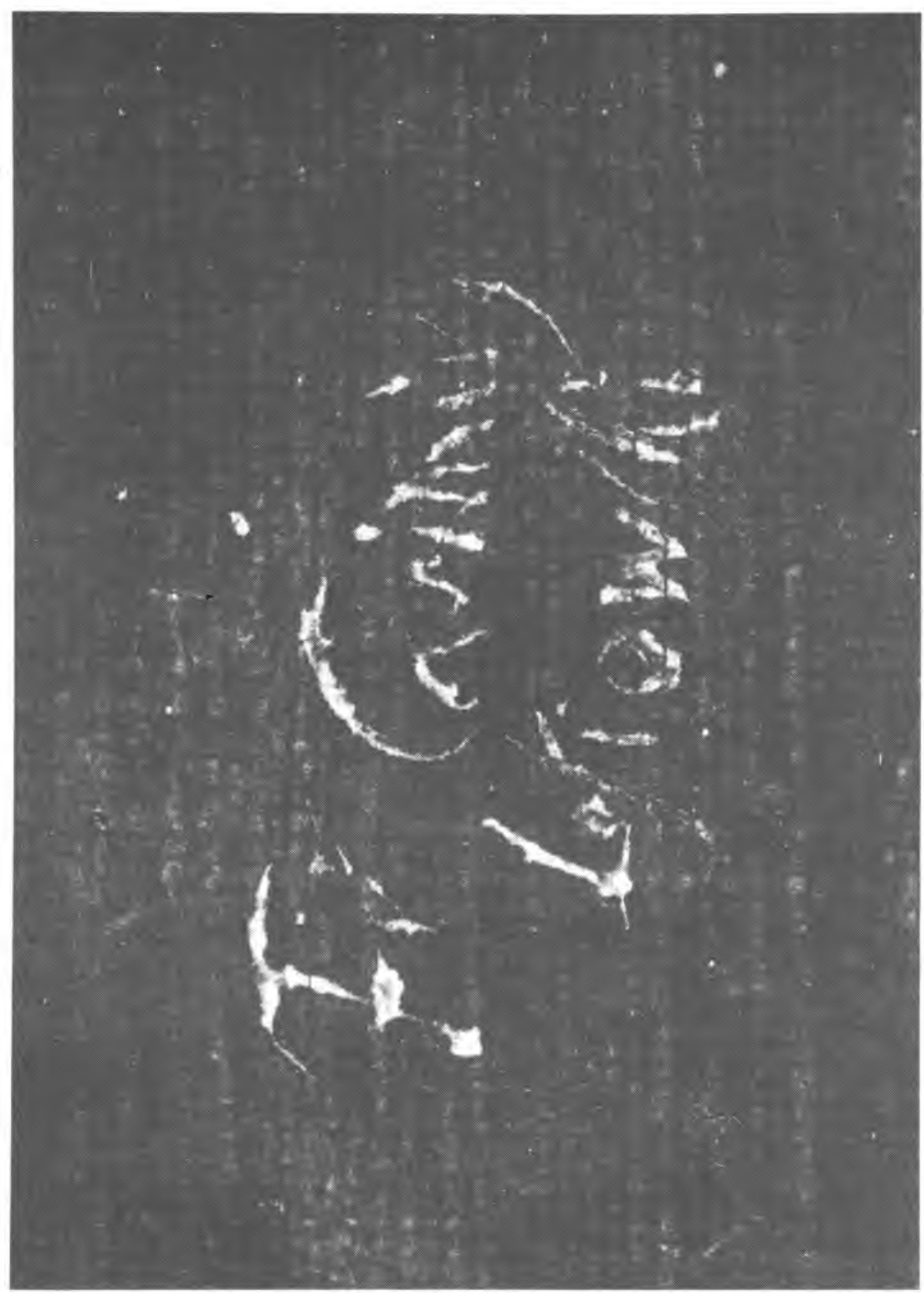

6. Sygnatura malarza, szczegół obrazu św. Antoniego z Padwy z r. 1648 w kapitularzu klasztoru klarysek przy kościele Św. Andrzeja w Krakowie (fot. M. Samek) 


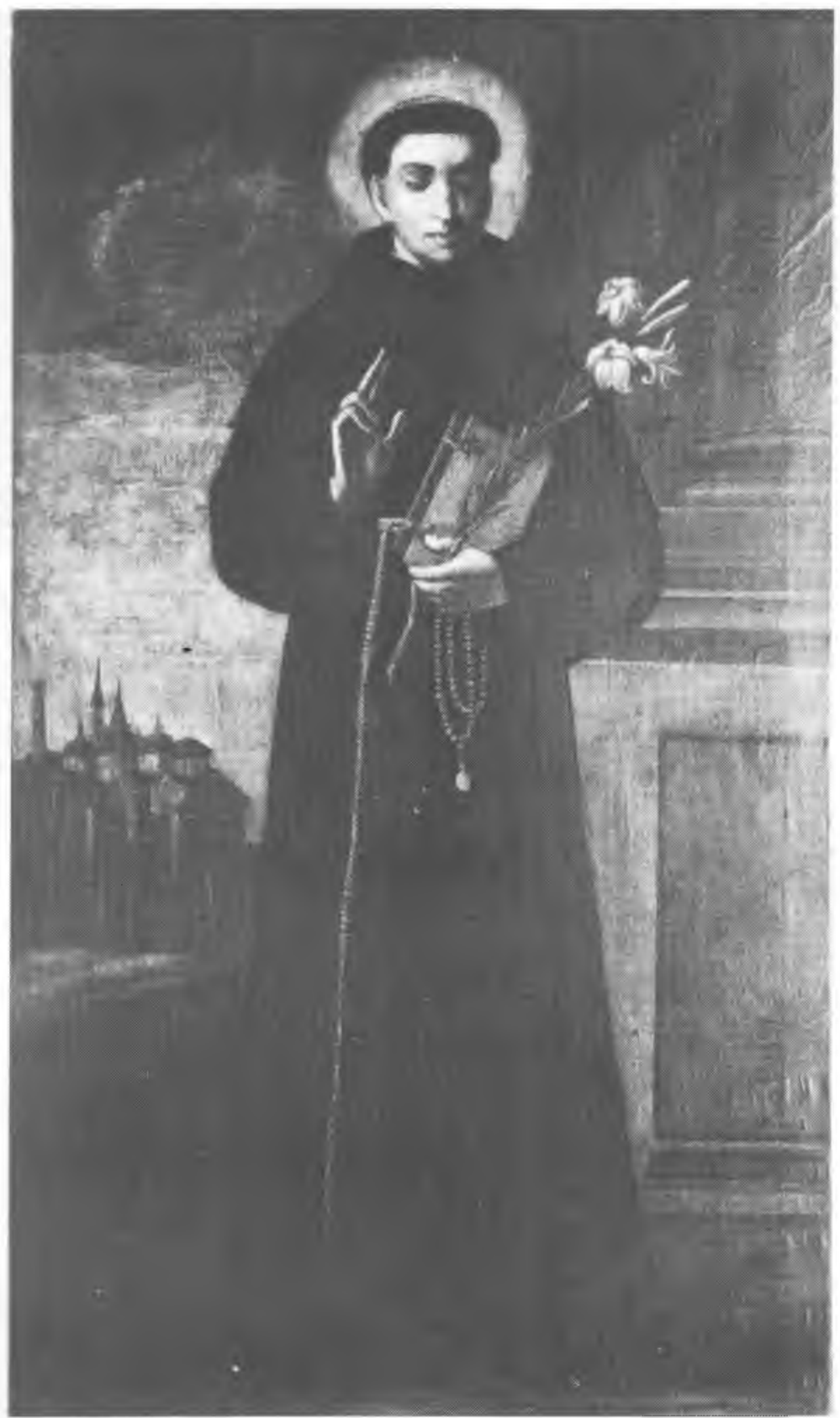

7. Św. Antoni z Padwy, obraz z 2. ćw. w. XVII, w refektarzu klasztoru franciszkanów w Krakowie (fot. J. Langda) 


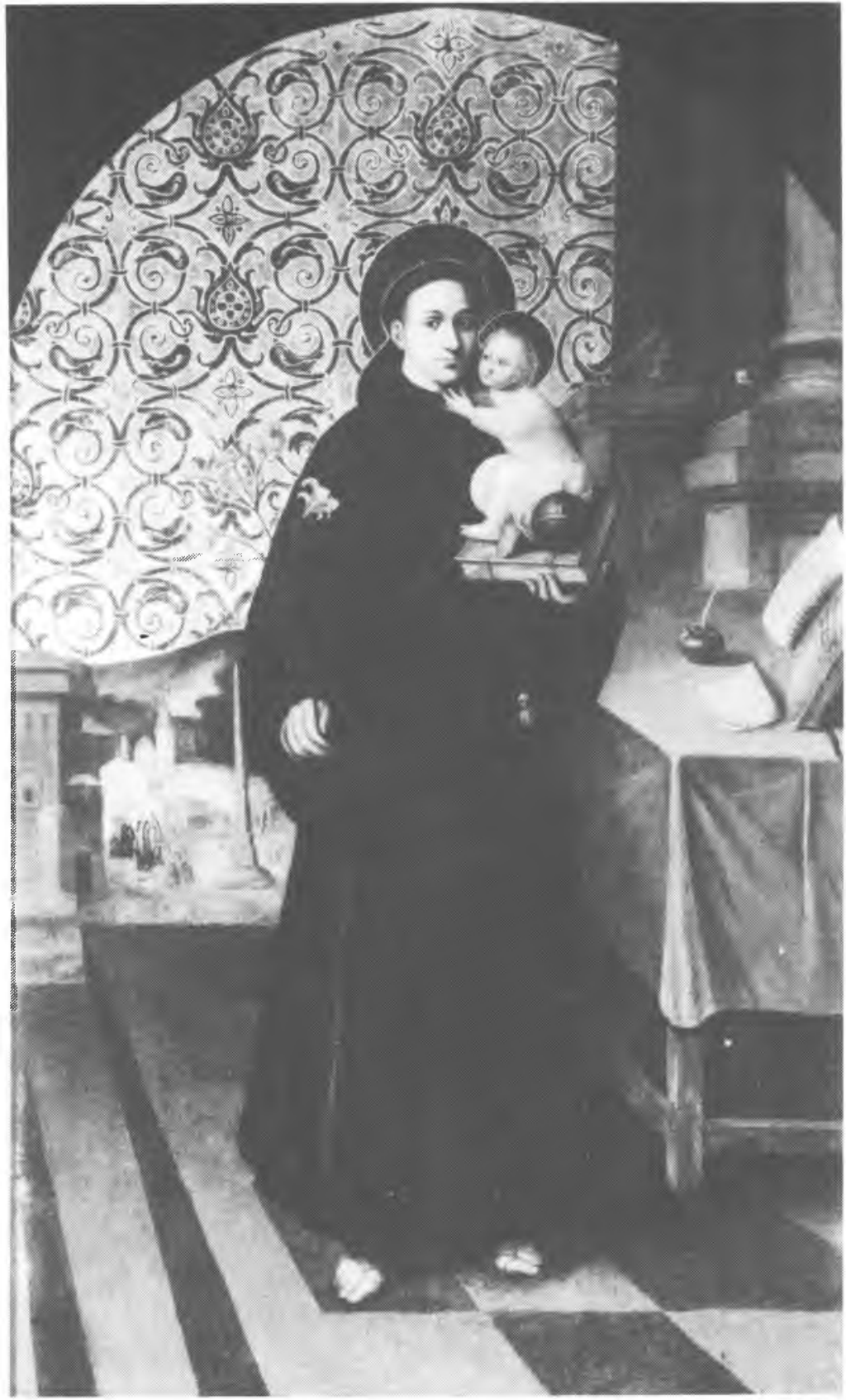

8. Św. Antoni z Padwy, obraz z r. 1664 w kościele franciszkanów w Warszawie (fot. wg M. Wolickiego, W. Tomkiewicza i A. Ryszkiewicza) 


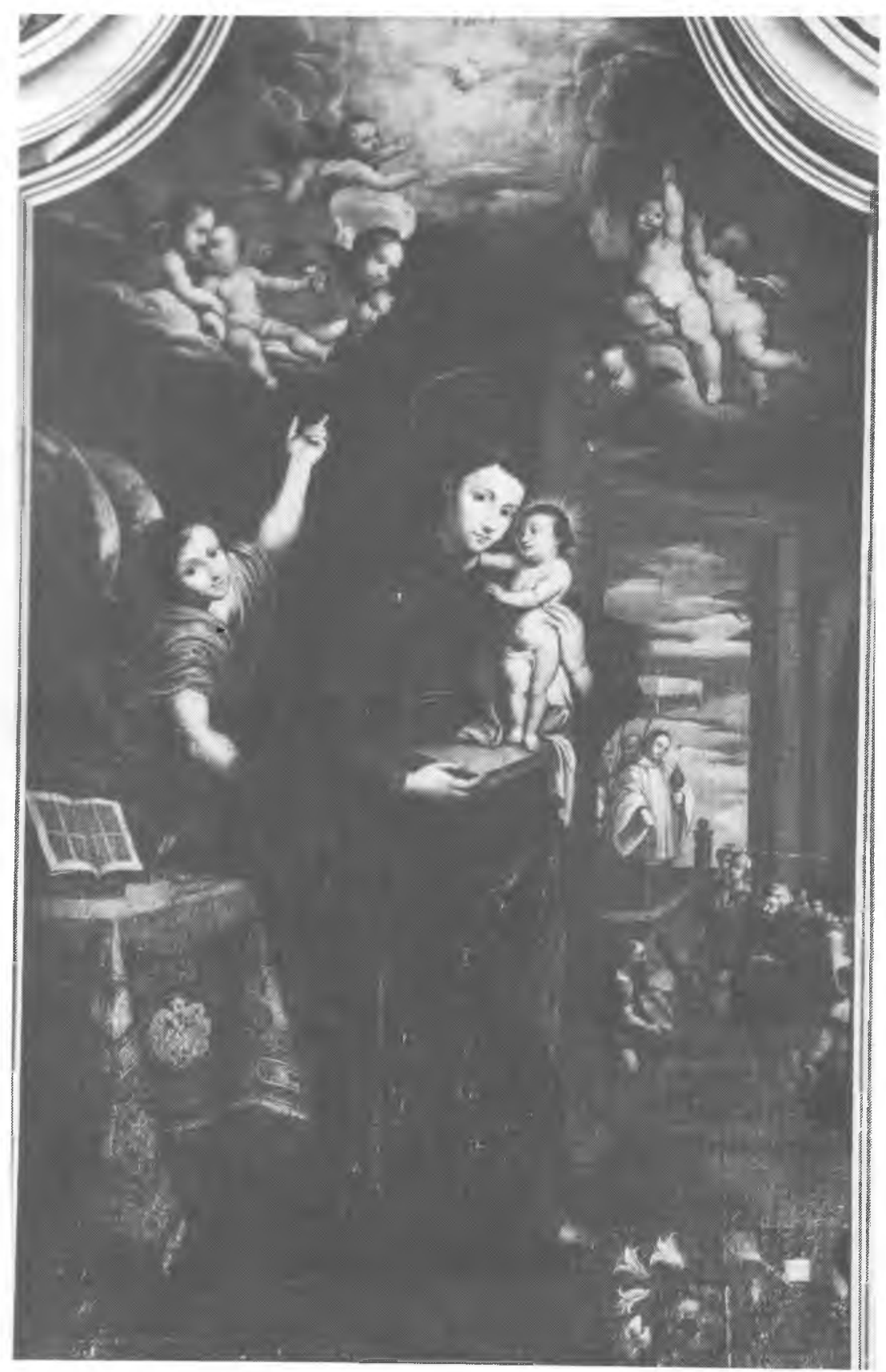

9. Św. Antoni z Padwy, obraz z 1. 1659-64 w oltarzu bocznym w kościele bernardynów w Krakowie (fot. J. Langda) 